\title{
Implication of Artisanal Mining in Indonesia in the Mining Minoral Perspective
}

\author{
M.Rochman \\ Student at Doctoral Program of Law \\ Universitas Borobudur \\ Jakarta, Indonesia \\ wiy ata_karya08@yahoo.co.id
}

\author{
Faisal Santiago \\ Faculty of Law \\ Universitas Borobudur \\ Jakarta, Indonesia \\ faisalsantiago@borobudur.ac.id
}

\begin{abstract}
Mining is a business that always gives big enough profit for a country that has natural resource-rich nature. Indonesia is a country rich in natural resources, Indonesia guarantees in Article 33 Paragraph (3) Undang Undang Dasar Negara Republik Indonesia Tahun 1945 (UUD NRI Tahun 1945) that natural resources are controlled by the state and used for the greatest prosperity of the society. In line with that, Indonesia gives the society of Indonesia can conduct a mining of the society and the mechanism of the Artisanal Mining is regulated in Law No. 4 of 2009 on Mineral and Coal Mining (Mining Law) and other Laws and Regulations. In History Indonesia has known the mining of the society from the Dutch colonial period until now. Currently the Artisanal Mining that provide prosperity for the community around the mining area has some problems both vertically and horizontally. Vertical conflict is related to the Society with the Government of which one of the illegal mining of society who do illegally. Horizontal conflict between communities is dispute for land for mining. This happened West Kalimantan Province in Pontianak horizontal conflict and vertical conflict happened upon the Artisanal Mining. Both Central and Local Government have arranged to create synergy policies that regulate the mining stages of the society from socialization to the public to disseminate information on the Artisanal Mining, after which the Determination of Artisanal Mining Areas (AMA). Then to facilitate the control of the right to apply for mining permit is a company incorporated Cooperative. From the existing AMA, the Mining Service will issue an Artisanal Mining Permit (AMP) to a cooperative that meets the formal requirements. There is an institution which will manage and monitor artisanal mining in order appropriate regulation. For avoid vertical conflict among the miner, there is a rule which regulate mechanism of property of license of artisanal mining area and mechanism of disinterment in order avoid conflict with other property. Last, Banishment of waste will be handled by $\mathrm{S}$ melter company and care about welfare to local society.
\end{abstract}

Keywords - implication, artisanal mining, mining law

\section{INTRODUCTION}

The mining sector in Indonesia is a sector that functions to get the largest foreign exchange, but the existence of mining activities and / or business in Indonesia is now widely questioned by various circles but in its implementation, the State often faced in dilemmatic condition between optimal utilization with environmental and social losses. This is due to the existence of mining business activities that have caused the impact of the exploitation of minerals.
Based on this, mining actors can be grouped with large scale mining, medium scale mining and also small scale mining in the form of Artisanal Mining. Mining activities pose many problems both to the environment and to the local community. That the mining problem is not only caused by large scale mining but small scale mining but does not mean has no problem.

Although it is cultivated traditionally but sometimes covers a large area, because it is cultivated by local communities with business actors who are not offset by equipment, facilities, knowledge, and capital. In addition to these limitations, regulatory constraints also exacerbate situations and conditions, so that artis anal mining tend to be unlicensed (Unlicensed Mining), so they are vulnerable to accidents and workplace safety, and sometimes cause pollution and uncontrolled environmental damage.

According to data collected by the Center for Mineral Technology Development, currently there are 77,000 small mining operations that produce almost all minerals for the industry worth about 58 million US dollars per year. Of that amount, it turned out that only three percent of those who have permission. So there are 74,500 mining operations that run the activity without permission. The low number of small-scale miners licensed by the govemment since the enactment of Law No. 11 of 1967, is due to the complicated and complicated bureaucratic bureaucracy issue. In addition to the issue of permits, public mining is not a governmentadmin istered priority. miners are not accompanied, in order to use technology that is safe for their safety and the environment. Managerial and funding capabilities and the ability to reduce environmental damage are other weaknesses of the people miners. Support to improve that capability is the task of the government if the mandate of the constitution to support mining activities for the sake of greatest prosperity of the people run.

The Artisanal Mining which is then regulated in the Minerba Act is about mining areas and licensing. CHAPTER $\mathrm{V}$ The Third Part of the Artisanal Mining Areas (AMA) article 20 through to Article 26 CHAPTER IX of Artisanal Mining Permit (AMP) article 66 to 73. A lthough the Minerba Act states that the determination of mining areas is carried out in partisiasi, taking into account the aspirations of the regions, community, but this Act has a weakness in the implementation of the recognition of community rights over living space. The community area is unilaterally used as a mining treasurer, including the neglect of the Artisanal Mining which is their right to life. The regulation of 
authority of regency / municipal government in the management of community mining based on Law Nu mber 4 Year 2009 concerning Mineral and Coal Mining requires the existence of regulation of regency / municipality as further, as well as the legal requirement and legal basis of local government in performing management of Artisanal Mining.

In the Pontianak region the regent or mayor may grant permission to traditional gold mining or community mining. Requirement, the location of the mine must be in the area pertambanagn people set by the government. head of mining ministry conservation and energy of West Kalimantan province, Bambang Santoso, explains that unauthorized operation makes monitoring difficult. The most visible impact is reclamation. Unlicensed artisanal mining usually leave the mine without reclamation, "said Bambang, an unlicensed gold mine in West Kalimantan, from 12 districts and two towns, only the city of Pontianak, which has no gold mining activities, has repeatedly arrested miners gold without permits, but mining activity is still rampant.

Associated with the right to control land by the state is contained in the provisions of Article 33 of the UUD NRI Tahun 1945 which states that the earth and water and natural resources contained therein are controlled by the state and used for the greatest prosperity of the people. "This shows that the utilization of the earth water, and the natural wealth in it solely to prosper the people by paying attention to the aspect of justice not for certain people but the masses.

Based on the UUD NRI Tahun 1945 Act above, the actual mining activities of the people can continue to exist, as long as they do not violate the existing rules, as long as they do not violate the rules that apply, both the rules of the State and local customary rules. The problem arises when the Artisanal Mining is not licensed and violates the existing rules. So that this can affect the environment and surrounding communities in the mining area, in order to know all problems related to the problem comprehensively.

\section{RESEARCH METHOD}

The research method used is normative research method (literature study) conducted by studying and reading scientific books, newspapers, papers seminar result, related legislation.

\section{PROBLEM}

1. How are Artisanal Mining arrangements in Indonesia?

2. How is the impact of illegal artisanal mining in the community?

\section{DISCUSSION}

\section{A. The setting of the Artisanal Mining in Indonesia}

Article 33 of the UUD NRI Tahun 1945 provides an overview of how Indonesia adopted these two ideas and Article 33 of the UUD NRI Tahun 1945 provides a juridical basis for Article 2 of Law no. 5 of 1960 concerning Agrarianism which first spoke about the conceptualization of Right to Country in a more technical level in the management of natural resources. Article 33 of the UUD NRI Tahun 1945 gives emphas is to the State's control over the Earth and Water and the natural wealth contained therein is controlled by the state and used for the greatest prosperity of the people. While Article 2 of Law no. 5 Year 1960 more clarify the scope of the rights of state, namely:

a. To organize and organize allotment, use, inventory and maintenance of the earth, water and aerospace;

b. Determine and regulate legal relationships between persons with the earth, water and space;

c. Determining and regulating legal relationships between persons and legal acts concerning earth, water and space or in other sentences can be concluded, the components contained in the rights of state are the power to regulate (relegen), administer (bestuuren ) and supervise (toezicthouden).

The first min ing rule to be enacted is Law no. 37 of 1960 . The Artisanal Mining is regulated in article 1 which determines that all types (a, b, and c) type of excavations cultivated by the people are small by simple means of selfsustenance according to local custom or cultivated cooperatively. In 1967, Law no. 11 of 1967 concerning the Minimum Provisions of Mining was enacted. Rights of state is expressly stated in Article 1 of Law no. 11 of 1967. This article states that all the minerals contained in the Indonesian mining jurisdiction which are natural sediments as a gift of God Almighty are the national treasures of the Indonesian nation and are therefore controlled and used by the State for the greatest pros perity of the people.

Law no. 11 of 1967 defines the artisinal mining as mining of minerals fromall classes a, b, and c as do the local people in small-scale or mutual assistance with simple tools for their own livelihood. Artisanal Mining aims to provide local people with the opportunity to excavate minerals to participate in developing countries in the mining sector with government guidance. the Artisanal Mining is only done by local people holding Mining Permits (Permits) of Artisanal Mining.

Law no. 11 Year 1967 implemented through the Government Regulation No. 32 of 1969. In this provision it is determined that the artisinal mining can be done after obtaining the Decree of Mining Permit issued by the Minister. Where the Decree of Mining Permit is the Mining Authority granted by the Minister to the local People to carry out small-scale mining business and with a very limited area.

Furthermore, some provisions are issued to regulate the this artisanal mining among them Ministerial Decree No Mining. 181 / Kpts / M / Pertamb / 69 on the Mining People's Arrangement for tin minerals in Riau Mainland, Ministerial Decree No. 188 / Kpts / M / Pertamb / 1969 concerning the Arrangement of Artisanal Mining for Gold Mining Material in Bengkulu Province, Mining Ministerial Decree no. 77 / Kpts / M / Pertamb / 1973 on the Arrangement of People Mining for Gold Mining Materials in Bolang Mongondow Region of North Sulawesi Province, Mining Ministerial Decree No. 763 / Kpts / M / Pertamb / 1974 concerning Regulation of People Mining Permit for kaolin excavation material in Karaha District Kab. Tasikmalaya West Java Province, Mining \& Energy Regulation No. 01 P / 201 / M / PE / 1986 regarding Guidelines for the Management of Small and Medium Strategic and Vital Materials (A \& B).

In Article 20 and Article 66 up to Article 73 of Law no. 4 of 2009 on Mineral and Coal accommodates the interests of the artisanal mining because in addition to solving the problems that have been happening, on the other hand is a 
concrete proof of recognition of the existence of the existence of the mine, which if done well, is one of the local economic potential that can move the economy in the area.

Two government regulations as the implementing regulation of Law no. 4 of 2009 on Mineral and Coal Mining has been published Government Regulation No. 22 of 2010 concerning Mining Areas and Govern ment Regulation no. 24 of 2012 on the Imple mentation of Mineral and Coal Mining Business Activities. In Article 26 and Article 27 of Government Regulation no. 22 of 2010 regulates the mining area, whereas in Article 47 and Article 48 Government Regulation 24 Year 2012 regarding the provision of AMP. In the case of the Artisanal Mining Permit, the community is granted AMP by the regent / mayor based on a request made by the local people, either individuals or community groups and / or cooperatives. However, even though there has been a legislative regulation that regulates the matter but the perpetrators of mining people are still many who do not have AMP (Illegal).

\section{B. The Impact of Illegal Mining on People}

It is recognized that the mining industry is benefiting the people, but on the other side the industrial sector also has a negative impact as stated by Nafsiatun, Priyo Saptomo, et al, that: "The industrial sector in addition to increasing and advancing the standard of people's lives, it is also a negative impact to people's lives. "

These negative impacts, including social conflict. According to Budy P. Resosudarmo, Ida Aju Pradnja Resosudarmo, et al, that: "Mining activities have been the source of various conflicts caused by policy and regulatory uncertainties over land use and property rights, illegal artisanal mining (artisanal mining is often, but not always , small scale; it can also refer to more and more related to legal mining companies, pollution and environmental impacts, and uncertainty surrounding the livelihoods of local residents aftermining closure.

To date, mining activities have been the source of many conflicts caused by policies and regulatory uncertainties over land use and property rights, illegal artisinal mining (Artisanal Mining is often, but not always, small-scale, but can also refer to more mining operations large and somewhat co-ordinated unrelated to legal mining companies), pollution and environmental impacts, and uncertainty surrounding the livelihoods of local residents after mine closure.

Based on data released by the Ministry of Environment and Forestry there are social conflicts in 84 (eighty four) locations based on field verification of 302 (three hundred and two) Unlicensed Mining locations. Social conflict is the impact of Unlicensed Mining in Indonesia. This social conflict occurs both between immigrants with local residents, between fellow citizens, as well as between residents and the authorities.

According to data from the Forum for the Environment (WALHI) in 2013 alone recorded the number of conflicts as much as 369 (tigas hundred sixty semibilan) cases with an area of conflict reached 1,281,660.09 hectares involving 139,874 heads of households (KK). Much increased sharply in the previous year, in 2012 the number of conflicts occurred as much as 198 (one hundred and ninety eight) cases or up $86.36 \%$ (eighty six point thirty six). In the last 6 years, there were 13 (thirteen) deaths, 125 (one hundred and twenty-five) wounded and 234 (two hundred and thirty) persons arrested for mining conflicts.

\section{CONCLUSIONS}

1. The regulation of Artis anal Mining is regulated in various legis lation of invitation, namely: Article 33 paragraph (3) of the UUD NRI Tahun 1945, Article 2 paragraph (3) of Law no. 5 of 1960 on Agrarian Law no. 4 of 2009 on Mineral and Coal Mining, Government Regulation No. 22 of 2010 on Mining Areas, Government Regulation No. 24 of 2012 on the Implementation of Mineral and Coal Mining Business Activities, Government Regulation No. 22 of 2010 on mining areas, and Government Regulation No. 24 Year 2012 on the Granting of AMP.

2. The illegal artisinal mining in the community affects the conflicts that occur between the people and the apparatus, between the immigrants and the local people and between the local people themselves. Illegal illegal mining activities have been the source of many conflicts caused by policies and regulatory uncertainties over land use and property rights, illegal artis anal mining.

\section{REFERENCES}

[1] Aspinall, Clive, Small Scale Mining in Indonesia Mining, Minerals and Sust ainable Development Journal No. 79, 2001., in press.

[2] Direktorat Pengusahaan Mineral dan Batubara, Pedoman Pengembangan Pengusahaan Pertambangan Skala Kecil, Jakarta, 2004., in press.

[3] Hamzah, Andi, Penegakan Hukum Lingkungan, Jakarta, Sinar Grafika, 2005.

[4] Inswiasri dan Hendro Martono, Pencemaran di Wilayah Tambang Emas Rakyat, Media Litbang Kesehatan Volume XVII No. 3, 2007., inpress.

[5] Salim Hs. H., Hukum Pertambangan Indonesia, Jakarta Raja Grafindo Persada, 2005.

[6] Sulaiman, Kewenangan Pemerintah Daerah Kabupaten dalam Pengelolaan Pertambangan Rakyat berdasarkan Undang-Undang No. 4 Tahun 2009 tentang Pertambangan Mineral dan Batubara, Jurnal Hukum Fakult as Hukum Univ. Mataram, 2013., in press.

[7] Sutedi, Adrian, Hukum Pertambangan, Jakarta, Sinar Grafika, 2011.

[8] Zulkarnain, Iskandar, etc, Dinamika dan Peran Pertambangan Rakyat di Indonesia, Jakarta, LIPI, 2007.

[9] Indonesia, Undang-Undang Dasar NRI Tahun 1945

[10] Indonesia, Law no. 5 of 1960 on the Basic Agrarian

[11] Indonesia, Law no. 4 of 2009 on Mineral and Coal Mining

[12] Indonesia, Government Regulation No. 22 of 2010 on Mining Areas

[13] Indonesia, Government Regulation No. 24 of 2012 on the Implementation of Mineral and Coal Mining Business Activities

[14] Indonesia, Government Regulation No. 22 of 2010 concerning mining areas

[15] Indonesia, Government Regulation No. 24 Year 2012 on Giving AMP 